\title{
DINAMIKA ISLAM POLITIK DAN ISLAM KULTURAL DI INDONESIA
}

\author{
LL Saefudin Zuhri \\ UIN Mataram \\ saefzuhri14@gmail.com
}

\begin{abstract}
This article discusses how the history of politics in Indonesia. The Islamic movement in Indonesia is so dynamic. This dynamic can be seen from the emerging Islamic movements, which can be grouped into two, namely the political Islam movement and cultural Islam. One of the dynamics that is still strongly discussed today is related to state ideology. Political Islam considers it necessary, while cultural Islam considers it unnecessary. Islam is most importantly embodied in the culture of society, not formalist. In conclusion, Islam does need to be embodied in cultural and political ways, but it does not need to be formalist. The two of them must complement each other. And The bigger the Islamic political movement at the ideological level causes the power of Muslims to weaken and experience stagnation. Therefore, in the Muslim struggle movement, another concept that moves culturally as an alternative is presented so that Muslims no longer experience delays in development.
\end{abstract}

Kata Kunci: Sosial Politik, Politik Islam, Islam Budaya

\section{A. Pendahuluan}

Ketika membaca Islam Indonesia selalu menarik minat banyak pengamat dan penikmat. Beberapa banyak sudut pandang pembacaan dan pendekataan. Termasuk ketika Kuntowijoyo membagi pengalaman Islam Indonesia ke dalam tiga fase: fase mitos, fase politik/deologis, dan fase ilmu/kultural. ${ }^{1}$ Fase-fase tersebut jika dipotretkan pada konteks Islam Indonesia mutakhir, terutama dari masa Orde Baru ke orde reformasi, ternyata telah memunculkan berbagai dinamika Islam Indonesia yang khas dan unik. Saya menyebutnya sebagai pergeseran dari Islam Kultural ke Islam politik.

Terdapat dua wajah Islam ${ }^{2}$ yang menjadi diskursus dalam paper ini yaitu "Islam Politik" dan "Islam Kultural." Islam politik mencerminkan upaya masuknya Islam dalam dunia politik yang berarti bahwa dalam hal ini tidak ada keterpisahan antara wilayah agama, hukum, ekonomi dan politik. Dengan konsep tersebut menyebabkan munculnya sejumlah partai politik yang berasaskan agama, baik Islam maupun Kristen. Sebagaimana yang disebut sebagai fenomena politik.

Sementara Islam kultural lahir sebagai wajah Islam yang lain, yang memposisikan Islam dengan negara menjadi sesuatu yang berbeda serta lebih mengedepankan etika

\footnotetext{
${ }^{1}$ Kuntowijoyo, Dinamika Sejaarah Islam Indonesi, (Yogyakarta: Salahuddin Perss 1991), 15.

${ }^{2}$ Wajah Islam dalam konteks ini sebagaimana yang dijelaskan oleh Azra adalah dua jenis Islam di mana yang pertama disebut Islam politik atau jenis Islam yang berorientasi kuat pada masalah politik dan kekuasaan. Adapun jenis Islam yang lainnya adalah Islam Kultural yaitu yang memiliki orientasi kepada aspek-aspek kemasyarakatan dan kultural tanpa melalui politik melainkan melalui media yang lain seperti dakwah Islam secara damai, atau melalui pengembangan pendidikan, ekonomi, kesehatan, lingkungan hidup dan lain sebagainya. Lihat. Azyumardi Azra, Revisitasi Islam Politik dan Islam Kultural di Indonesia, Indo-Islamika, Vol.1 No.2 (2012), 223-224.
} 
dan moral. ${ }^{3}$ Dapat dikatakan munculnya Islam kultural sebagai tanding dari meredupnya Masyumi sebagai partai basis Islam terbesar pada kancah politik nasional.

Dalam sejarah Indonesia, Islam merupakan suatu kekuatan yang sangat berperan dalam perlawanan menentang penjajah. Islam pada masa itu merupakan salah satu garda terdepan dalam mengusir penjajahan. ${ }^{4}$ Dalam rangka mengusir penjajahan tersebut diperlukan alat organisasi sebagai penyatu aspirasi dan tujuan. Maka tercatatlah berdirinya Sarekat Islam (SI), organisasi pertama kekuatan politik yang anggotanya terbanyak di antara organisasi-organisasi pergerakan lainnya.

Selanjutnya pascakemerdekaan Indonesia, keluarlah maklumat wakil presiden no.X tahun 1945 yang memperbolehkan berdirinya partai-partai politik. Umat Islam merespon maklumat tersebut dengan mendirikan partai politik Masyumi. ${ }^{5}$ Berdirinya Masyumi ini dimaksudkan sebagai satu-satunya partai politik yang akan memperjuangkan aspirasi dan nasib umat Islam Indonesia. Partai politik ini didukung oleh dua ormas Islam yang terbesar, yaitu NU dan Muhammadiyah. Namun dalam perjalanannya satu persatu pendukung Masyumi keluar dimulai dari PSII tahun 1947, menyusul kemudian NU $1952 .{ }^{6}$ Akibatnya pada pemilu pertama, kekuatan politik islam terpecah belah yang menyebabkan kekuatan partai Islam menjadi melemah. Melemahnya partai islam nampaknya mengakibatkan Islam politik menjadi terpinggirkan. Politik Islam dalam rangkaian percaturan politik di masa-masa awal kemerdekaan sampai masa orde baru lebih banyak berorientasi pada masalah ideologi negara. hal ini menyebabkan politik Islam cendrung dianggap mengganggu stabilitas politik, dan karena itu menghambat pembangunan. Konsekuensinya adalah partai Masyumi di bubarkan dan partai-partai Islam tidak banyak mendapat dukungan.

Dengan melemahnya kekuatan politik umat Islam muncul para pembaharu muda yang menawarkan sebuah gerakan pembaharuan Islam dari dimensi ritual dan kemasyarakatan. Gerakan ini yang disebut gerakan Islam kultural ${ }^{7}$ yang menawarkan wacana bahwa gerakan Islam tidak harus berkutat dalam bidang politik, tetapi dalam wilayah kultural. Dengan hadirnya gerakan Islam kultural ini maka Islam hadir sebagai nilai-nilai dan sumber etik. Namun bukan berarti mengosongkan kesadaran umat dari dunia politik. Dalam konsep Islam Kultural, Power Politics bukanlah satu-satunya alternatif bagi perjuangan Islam di Indonesia tetapi juga terdapat sarana lain bagi keberhasilan perjuangan tersebut antara lain melalui dakwah, pendidikan, sosial, ekonomi, budaya dan lain sebagainya.

Selanjutnya, Pada era reformasi muncul kembali partai-partai politik Islam dengan formasi baru yang tidak bertentangan dengan ideologi negara. Terdapat banyak partai Islam atau partai yang berbasis dukungan umat Islam, seperti Partai Persatuan Pembangnunan (PPP), Partai Syarikat Islam Indonesia (PSII), Partai Ummat Islam 2013), 274

${ }^{3}$ M. Mukhsin Jamil, Revitalisasi Islam Kultural, Jurnal Walisongo Vol.21 No.2 (November

${ }^{4}$ Ngatawi Al-Zastrouw, Mengenal Sepintas Islam Nusantara, Indonesian Journal of Multidisciplinary Islamic Studies,Vol.1, No.1, (Januari 2017), 1-18

${ }^{5}$ Munculnya Masyumi dipandang sebagai manifesto politik Wakil Presiden Hatta tertanggal 1 November 1945 yang mendorong pembentukan partai-partai. Lihat, Ahmad Syafii Maarif, Islam dan Pancasila Sebagai DasarNegara: Studi Tentang Perdebatan dalam Konstituante, Cet I (Bandung:Mizan, 2017), 152.

${ }^{6}$ Ahmad Syafii Maarif, Islam dan Pancasila Sebagai DasarNegara: Studi Tentang Perdebatan dalam Konstituante, Cet I (Bandung:Mizan, 2017), 157.

${ }^{7}$ Muh. Syamsuddin dan Muh. Fatkhan, Dinamika Islam Pada Masa Orde Baru, Jurnal Dakwah, Vol.XI No.2 (Juli-Desember 2010), 140. 
(PUI), Partai Masyumi Baru, Partai Bulan Bintang (PBB), Partai Keadilan Sejahtera(PKS), Partai Nahdhatul Ummat (PNU), Partai Amanat Nasional (PAN), Partai Kebangkitan Bangsa (PKB), dan yang lainnya.

Ada beberapa kelompok berpandangan bahwa, Islam diperjuangkan melalui jalur politik. Artinya bahwa perlunya menggunakan atribut Islam unutuk menegakkan hukum-hukum Islam melalui jalur politik. Sedangkan kelompok yang kedua mempunyai kepercayaan bahwa, untuk menyampaikan aspirasi-aspirasi Islam tidak mesti dengan jalan politik, karena politik identik dengan banyaknya perilaku yang tidak bermoral.

Nirkholis Majid menyayangkan berdirinya kembali partai-partai Islam. Ia menganggap bahwa pendirian partai-partai Islam tersebut merupakan gejala tumbuhnya komunalisme. Adapun penilaian yang seperti ini bisa difahami karena memang Nurkholis Majid dikenal sebagai orang yang berpandangann tidak perlu adanya partai politik Islam karena, ia merupakan penggagas Islam kultural. Maka, dalam makalah ini membahas tentang Islam politik dan Islam kultural secara global yang mewarnai panggung Indonesia.

\section{B. Histori Islam Politik dan Islam Kultural}

Hubungan Islam dan politik di Indonesia senantiasa berkembang dari waktu ke waktu. Umat Islam sebagai penduduk mayoritas merasa perlu untuk berpartisipasi aktif di bidang politik. Aspirasi Muslim terhadap politik memiliki sejarah dan jejak perkembangan yang panjang dalam pentas perpolitikan Indonesia, dari masa kerajaan Islam hingga Era Reformasi.

Dalam pemahaman Islam kultural dalam konteks ke Indonesiaan adalah Islam dakwah, Islam seni, yang identik dengan kentalnya pemahaman syariat agama yaitu "Islam Ibadah" dan Islam Masjid". Sementara pendapat mengenai Islam politik merupakan Islam yang berusaha di wujudkan dan di aktualisasikan dalam bentuk kekuasaan atau dalam kelembagaan politik resmi, khususnya dalam bidang pemerintahan baik itu legislatife mapun yudikatif. ${ }^{8}$

Gencarnya pembagian yang dianggap sebagai sebuah pemisah antar Islam politik dan Islam kultural sedah agak lama dilmulai, dengan di sertai sikap seakan-akan banyak yang beranggapan Islam politik kurang cocok dengan keadaan masa sekarang, dan ini sudah di dengung-dengungkan sejak awal Orde Baru. Yang Islam kultural itulah yang dinilai banyak orang akan menyampaikan umat Islam pada masa kejayaannya.

Tetapi kalau kita berbicara masalah historis, maka pemisah antara Islam politik dan Islam kultural adalah kebijaksanaan yang dianjurkan oleh pakar Islam seperti C. Snouck Hurgronje kepada pemerintahan pada saat itu. Yaitu agar pemerintahan Hindia Belanda membiarkan Islam ibadah, tetapi malah menghalangi Islam politik. Pada saat itu, pemerintah Belanda malah turut membantu masyarakat Islam, antara lain bentuk bentuk bantuannya membangun Masjid di Palembang dan Kota Raja dan lain-lain. Mereka malah melarang gereja dilarang didirikan di Aceh dan Banten. Dan juga mengenai perjalanan ibadah haji, yang pada saat itu dipersulit,dengan nasehat $\mathrm{C}$. Snouck Hurgronje bisa dipermudah oleh pemerintahan Belanda pada saat itu. ${ }^{9}$

\footnotetext{
${ }^{8}$ Azyumardi Azra, "Islam Politik dan Islam Kultural": Islam Masa Pasca-Soehartoll, dalam Arif Subhan, Inodnesia dalam Transisi Menuju Demokrasi, (Jakarta: LSAF, 1999), 75.

${ }^{9}$ Deliar Noer, Islam dan Politik, dalam Hamid Habaib, dkk, Mengapa Partai Islam Kalah?: Perjalanan Politik Islam dari Prapemilu '99 sampai Pemilihan Presiden, (Jakarta: Alvaabet: 1999), 8-11.
} 
Adapun yang dikemukakan tentang Islam structural oleh Masykuri Abdillah dalam makalahnya "Islam Politik dan Islam Struktural" mengatakan, bahwa untuk membedakan istilah-istilah tersebut, setidaknya ada dua perspektif yang perlu dikemukakan. Pertama, adalah sosialisasi dan institusionalisasi ajaran Islam, termasuk dalam konteks transformasi sosial dan pembentukan sistem nasional, yang dikelompokkan ke dalam Islam kultural dan Islam struktural. Islam yang pertama mengandung pengertian bahwa sosialisasi dan institusionalisasi ajaran Islam dilakukan melalui upaya-upaya yang menakankan pada perubahan kesadaran dan tingkah laku umat/masyarakat tanpa keterlibatan negara dan tanpa perubahan sistem nasional menjadi sistem yang Islami. Sedangkan yang kedua, Islam struktural, menekankan adanya upaya-upaya penetapan sistem nasional maupun kebijakan publik yang Islami. Padahal upaya semacam ini tidak mesti dilakukan melalui partai politik berlabel Islam, kendati tentu saja membutuhkan adanya political will dari para pengambil kebijakan. ${ }^{10}$

\section{Islam dan Politik dalam konteks ke Indonesia}

Pada persentuhannya dengan wilayah politik, Islam dalam aplikasi sosiologisnya kadang mencerahkan sejarah dan peradaban atau sebaliknya menggelapkannya. Islam, seperti agama-agama dan narasi besar lainnya, kadang menjadi kekuatan positif dan kadang menjadi kekuatan negatif, kadang merawat dan memekarkan hidup, tapi kadang juga agresif dan destruktif. Islam bisa menjadi salah satu kekuatan demokratisasi atau sebaliknya menjadi penghambat demokrasi. Pendek kata, Islam bisa menjadi energi untuk humanisasi atau dehumanisasi. Kendati wacana politik Islam di Indonesia sudah ada sejak abad ke-17, akibat hubungan politis dengan dunia luar (Timur Tengah)Mengenai hubungan agama dan negara dalam kehidupan kebangsaan kontemporer sudah barang tentu harus diletakkan dalam konteks kebutuhan untuk mewujudkan kehidupan negara yang lebih maju dan beradab. Kemajuandan keberadaban itu antara lain ditandai dengan keseimbangan antara negara (state) dan masyarakat beradab (civil society). Secara konseptual dinamika keseimbangan negara dan civil society akan ditentukan olehmodel-model negara itu sendiri. ${ }^{11}$

Secara teoritis dalam pemikiran politik Islam terdapat tiga paradigma tentang masalah hubungan agama dengan Negara. ${ }^{12}$ Pertama, paradigma yang menyatakan bahwa antara agama dan negara merupakan kesatuan yang tidak terpisahkan (integrated). Kedua, Paradigma yang menyatakan bahwa antara agama dan negara meruapakan sesuatu yang saling berkaitan dan berhubungan (simbiotik). Ketiga, paradigma yang menyatakan bahwa antara agama dan negara merupakan suatu yang harus terpisah (sekularistik).

Maraknya partai-partai Islam pasca orde baru telah menimbulkan perdebatan yang kontroversial karena representasi dari gerakan politik islam tercermin dari politik partai itu sendiri. Artinya partai politik Islam membawa Pemikiran politik mereka masing-

${ }^{10}$ Masykuri Abdillah, Islam Politik dan Islam Struktural, dalam Hamid Habaib, dkk, Mengapa Partai Islam Kalah?: Perjalanan Politik Islam dari Prapemilu '99 sampai Pemilihan Presiden, (Jakarta: Alvaabet: 1999), 13.

${ }^{11}$ Hubungan politis ini diakui oleh Azyumardi Azra, kendati lebih bersifat keagamaan dan keilmuan. Lihat lebih lanjut tulisan Azyumardi Azra, Jaringan Ulama (Bandung: Mizan, 1998), 16-17.

${ }^{12}$ Din Syamsuddin menyebutnya atas ketiga hal tersebut terdiri dari paradigma integrated, simbiotik, dan sekularistik. SementaraUmaruddin Masdar menyebutnya dengan konservatif, modernis, dan liberal. Lihat DinSyamsuddin, "Usaha Pencarian Konsep NegaraDalam Sejarah Pemikiran Politik Islam”, Ulumul Qur'an, No.2 Vol.IV tahun 1993. Umaruddin, Membaca Pikiran Gus Dur dan Amien RaisTentang Demokrasi, (Yogyakarta: Pustaka Pelajar, 1999), 20. 
masing. Bagaimana partai memahami islam dan mengimplementasikan politiknya sesuai dengan nilai - nilai islam atau sebaliknya partai islam hanya memanfaatkan simbol untuk menarik dukungan suara dari masyarakat islam. ${ }^{13}$ Fenomena itu dinilai sebagai perwujudan dari hadirnya kembali politik Islam, atau yang diistilahkan sebagai "repolitisasi Islam". ${ }^{14}$ Repolitisasi bisa bermakna ganda, penilaian pertama bernada positif karena seperti agama-agama lain, Islam tidak bisa dipisahkan dari politik. Penilaian kedua, jika istilah itu dipahami secara benar, adalah negatif. Istilah "politisasi" (terhadap apa saja) selalu dipersepsikan sebagai bagian dari rekayasa yang bersifat pejorative atau manipulatif.

Kemunculan partai-partai Islam di indonesia merupakan representasi dari umat Islam yang bergerak dalam bidang politik. Beberapa partai politik islam yang pernah ikut dalam pergulatan politik di Indonesia diantaranya: Pertama, partai politik di masamasa awal kemerdekaan yang diwakili oleh Masyumi dan NU pada pemilu 1955. Selanjutnya pada pemilu 1971 diwakili oleh Partai Serikat Islam Indonesia (PSII), Nahdlatul Ulama (NU), Partai Muslimin Indonesia (PMI) Partai Islam (PERTI).

\section{Genealogi Perkembangan Politik Islam di Indonesia}

Relasi Islam dan politik di Indonesia senantiasa berkembang dari waktu ke waktu. Umat Islam sebagai penduduk mayoritas merasa perlu untuk berpartisipasi aktif di bidang politik. Aspirasi Muslim terhadap politik memiliki sejarah dan jejak perkembangan yang panjang dalam pentas perpolitikan Indonesia, dari masa kerajaan Islam hingga Era Reformasi. Namun di bawah ini penulis membatasi perkembangan sejarah politik Islam hingga masa Orde Baru untuk mengantar pada pembahasan mengenai Islam kultural dan kembali munculnya politik islam di era transformasi

\section{Masa Pra-Kemerdekaan}

Kedatangan Belanda di akhir abad ke-16 dan awal abad ke-17 menjadi babak pembuka penderitaan bangsa Indonesia. Beralihnya motif Belanda dari kepentingan ekonomi menjadi kolonialisasi di abad ke-17 sampai abad ke-18, ${ }^{15}$ memunculkan berbagai reaksi dari penduduk pribumi. Penduduk Indonesia yang mayoritas beragama Islam merupakan kenyataan yang harus diterima oleh Belanda. Berbagai perlawanan seperti perang Paderi di Minangkabau (1821-1827), perang Diponegoro yang terjadi di Jawa (1825-1830), perang Aceh (1837-1903), dan perang lainnya tidak terlepas dari sendi Islam. ${ }^{16}$

Pada tahun 1905, terdapat gerakan pembaharuan agama yang diprakarsai oleh komunitas Arab di Batavia, yaitu Jam'iyyat Khair. Perserikatan ini mendirikan sekolah yang mendatangkan gurunya dari kalangan Islam modernis yang bernama Syeikh Ahmad Surkati. Menyusul kemudian, gerakan dari al-Irsyad yang dibentuk oleh Surkati pada tahun 1915. Gerakan ini mendirikan sekolah yang sebagian besar muridnya keturunan Arab dan sebagiannya lagi penduduk pribumi. ${ }^{17}$

${ }^{13}$ Lili Romli, Partai Islam dan Pemilih Islam di Indonesia, Jurnal Penelitian Politik, Vol. 1 No.1 (2004), 29-48

${ }^{14}$ Basam Tibi menjelaskan bahwa repolitisasi Islam mengandung makna bahwa Islam di-jadikan sebagi ideologi politik. Rijal Mumazziq Zionis, Konsep Kenegaraan dalam Islam : Perdebatan yang tak kunjung Tuntas,Jurnal Falasifa, Vol.1 No.2 (September 2010), h. 119. bandingkan dengan, Bassam Tibi, Krisis Modern dalam Peradaban Islam, 163.

${ }^{15}$ Didin Saefuddin Buchori, Sejarah Politik Islam(Jakarta: Pustaka Intermasa, 2009), h. 299-301.

${ }^{16}$ Zaprulkhan, Dinamika Pemikiran Politik Islam di Indonesia, Jurnal review Politik Vol.3 No. 2 (Desember 2013), 156.

${ }^{17}$ M.C. Ricklefs, A History of Modern Indonesia Since c. 1200, (London: Palgrave, 2001), 215. 
Reaksi lainnya atas kolonialisme Belanda adalah berdirinya organisasi Budi Utomo yang digagas oleh Dr. Wahidin. Pendiri organisasi ini menganggap bahwa salah satu faktor kemunduran masyarakat Jawa adalah kedatangan Islam. ${ }^{18}$ Gagasan-gasan Budi Utomo bertolak pada pemimpin India, Tagore dan Ghandi, yang dijadikan sebagai teladan dalam kebangkitan nasional. Namun, penduduk Indonesia lebih banyak yang terpengaruh dengan cita-cita yang didasarkan pada prinsip Islam. ${ }^{19}$ Oleh karena itu, tampak juga pergerakan-pergerakan nasionalis di Jawa. Kelompok-kelompok Islam reformis seperti Serekat Islam dan Muhammadiyah yang didirikan tahun 1912, ${ }^{20}$ mewakili tindakan-tindakan yang berdasarkan pergerakan massal. ${ }^{21}$ Masa ini disebutsebut dengan masa kebangkitan nasionalisme Indonesia.

SI (Serekat Islam) berkembang menjadi organisasi politik Indonesia yang menuntut kemerdekaan penuh atas Indonesia. ${ }^{22}$ Organisasi ini dipimpin oleh H.O.S Tjokroaminoto yang sebelumnya dipegang oleh Samanhudi atas dorongan Tirtoadisurjo. ${ }^{23}$ Gerakan SI memiliki misi untuk memakmurkan dan mensejahterakan rakyat Muslim, ${ }^{24}$ maka tidak heran jika pada perjalanannya organisasi ini memiliki pengikut yang banyak dan berkembang pesat. Pada tahun 1919, SI menyatakan memiliki 2 juta anggota, meskipun jumlah sebenarnya tidak lebih dari setengah juta orang. ${ }^{25}$ Namun, kepopuleran SI tidak bisa dipertahankan di tahun 1920 dalam meraih kemerdekaan, selain itu muncul perpecahan disebabkan permasalahan internal dalam tubuh SI sendiri. ${ }^{26}$

\footnotetext{
${ }^{18}$ Pandangan ini pada gilirannya berubah, Budi Utomo sempat menjadikan daya tarik Islam sebagai cara untuk menarik massa dan memperluas ruang lingkup kegiatannya ke luar Jawa dan Madura. Lihat M.C. Ricklefs, A History of Modern Indonesia Since c. 1200, (London: Palgrave, 2001), 207 dan 371.

${ }^{19}$ Bernard H. M. Vlekke, Nusantara; Sejarah Indonesia, terj. Samsudin Berlian(Jakarta: PT Gramedia, 2008), 392.

${ }^{20}$ Ada perbedaan pendapat mengenai berdirinya Organisasi Sarekat Islam. Sukron Kamil menyebutkan lahirnya Serekat Islam ini pada tahun 1911. Hal ini senada dengan apa yang ditulis oleh Didin Saefuddin dalam bukunya Sejarah Politik Islam. Namun menurut Adam Scharz, Bernard H.M. Viekke dan M.C. Ricklefslahirnya kelompok reformis Islam tersebut di tahun 1912. Hemat penulis, perbedaan tahun lahirnya SI disebabkan karena organisasi ini kelanjutan dari Serekat Dagang Islam yang berdiri pada tahun 1911.

${ }^{21}$ Adam Scharz, A Nation in Waiting; Indonesia's Search for Stability, (United States of America: Westview Press, 2000), 4.

${ }^{22}$ Sukron Kamil, Islam dan Politik di Indonesia Terkini; Islam dan Negara, Dakwah dan Politik, HMI, Anti-Korupsi, Demokrasi, NI, MMI, dan Perda Syari'ah, (Ciputat: Pusat Studi Indonesia dan Arab, 2013), hlm. 4. Namun, sebenarnya gerakan ini memiliki kebijakan yang berbeda-beda, seperti kebijakan Islam militan, anti komunis, anti belanda dan menunjukkan pergerakan nasionalis. Lihat Zaprulkhan, "Dinamika Pemikiran Politik Islam di Indonesia"dalam Jurnal Review Politik (Surabaya: UIN Sunan Ampel), Vol. 3, No. 2, Desember 2013, hlm. 157. Mengenai program organisasi ini, diantaranya; 1) Promosi usaha komersial di antara orang Indonesia, 2) Pengorganisasian dukungan timbal-balik dalam bidang ekonomi, 3) Promosi kesejahteraan intelektual dan materiil orang Indonesia, 4) Promosi Islam. (Dikutip dari Bernard H. M. Vlekke, Nusantara; Sejarah Indonesia, terj. Samsudin Berlian(Jakarta: PT Gramedia, 2008), 394.

${ }^{23}$ M.C. Ricklefs, A History of Modern Indonesia Since c. 1200, (London: Palgrave, 2001), 210.

${ }^{24}$ Zaprulkhan, "Dinamika Pemikiran Politik Islam di Indonesia"dalam Jurnal Review Politik (Surabaya: UIN Sunan Ampel), Vol. 3, No. 2, Desember 2013, 157.

${ }^{25}$ M.C. Ricklefs, A History of Modern Indonesia Since c. 1200, (London: Palgrave, 2001), 210.

${ }^{26}$ Sukron Kamil, Islam dan Politik di Indonesia Terkini; Islam dan Negara, Dakwah dan Politik, HMI, Anti-Korupsi, Demokrasi, NI, MMI, dan Perda Syari'ah, (Ciputat: Pusat Studi Indonesia dan Arab, 2013), 4.
} 
Selanjutnya, Muhammadiyah sebagai kelompok Islam reformis yang diprakarsai oleh KH Ahmad Dahlan dengan cepat gagasan-gagasannya diterima dan menjadi poluler. ${ }^{27}$ Pengalaman KH Ahmad Dahlan yang pernah masuk dalam keorganisasian Budi Utomo dan pengamatannya terhadap organisasi Islam lainnya seperti Serekat Islam dan Jam'iyyat Khair menjadi latar belakang terbentuknya Organisasi Muhammadiyah. Organisasi yang dibentuknya tersebut diwujudkan untuk masyarakat pribumi yang mengedepankan gerakan modernisme Islam. Pada tahun 1920, organisasi Muhammadiyah telah tersebar di berbagai daerah di Indonesia, diantaranya Minangkabau, Pekalongan, Surabaya, Bengkulu, Banjarmasin, Amuntai, Aceh dan Makassar. $^{28}$

Pada tahun 1920-an, lahir pula organisasi pembaharuan Islam, yaitu Persatuan Islam (Persis) dan NU (Nahdhatul 'Ulama). Persis yang dibentuk oleh KH Zamzam ini lahir pada tahun 1923 di Bandung. Organisasi ini tidak terlalu bergairah untuk menambah banyak anggota. Kegiatan Persis lebih mengutamakan dakwah lisan dan tulisan, seperti menerbitkan buku dan majalah, ceramah, dan aktif di media massa. ${ }^{29}$ Selanjutnya, organisasi NU lahir di tahun 1926 yang didirikan oleh KH Wahab Hasbullah dan didukung oleh KH Hasyim Asy'ari. Lahirnya organisasi ini dilatarbelakangi oleh keengganan terhadap kaum modernisme dan hendak membela kepentingan kaum tradisionalis. Gerakan organisasi ini cukup pesat, pada tahun 1942, sudah memiliki 120 cabang di Jawa dan Kalimantan Selatan. ${ }^{30}$ Kemudian di tahun 1930, muncul organisasi pembaharu Islam di Bukittinggi yang bernama Perti (Pergerakan Tarbiyah Islamiyah). ${ }^{31}$

Seiring dengan perkembangan pergerakan Muslim, dan pada tahun 1926 dengan ditumpasnya pemberontakan PKI dan ketidakaktifan lagi SI, Soekarno dan Algemeene mendirikan sebuah partai politik baru. Politik tersebut bernama Perserikatan Nasional Indonesia yang menuntut kemerdekaan Kepulauan Indonesia dengan cara nonkooperatif dan dengan organisasi massa. ${ }^{32}$ Dengan adanya partai PNI, menunjukkan bahwa terdapat dua ideologi nasionalisme di Indonesia. Partai PNI mewakili nasionalis sekuler dan SI mewakili nasionalis Islam. ${ }^{33}$

Setelah Belanda ditumbangkan oleh Jepang pada tahun 1942, penjajah Jepang melihat bahwa kaum santri bisa membantu mereka dalam hal administrasi wilayah Indonesia. Mereka juga berasumsi bahwa orang-orang yang disekolahkan oleh Belanda tentu akan bersimpati pada Belanda dan Eropa. Oleh karena itu, untuk mendapatkan kepercayaan, Jepang memihak kepada santri. ${ }^{34}$ Selama masa penjajahan Jepang (19421945), kekuatan politik Islam semakin menguat. Hal ini karena kebijakan-kebijakan Jepang yang memberikan ruang kepada Muslim Indonesia untuk mengekspresikan

\footnotetext{
${ }^{27}$ Greg Barton, Abdurrahman Wahid; Muslim Democrat, Indonesian President, (Australia: UNSW Press book, 2002), 70.

${ }^{28}$ Didin Saefuddin Buchori, Sejarah Politik Islam(Jakarta: Pustaka Intermasa, 2009), 307-308.

${ }^{29}$ Didin Saefuddin Buchori, Sejarah Politik Islam(Jakarta: Pustaka Intermasa, 2009), 309-310.

${ }^{30}$ M.C. Ricklefs, A History of Modern Indonesia Since c. 1200, (London: Palgrave, 2001), 223.

${ }^{31}$ Faisal Ismail, Islam, Politics and Ideology in Indonesia; A Study of The Process of Muslim Acceptance of The Pancasila, (Montreal: Canada, 1995), 8.

${ }^{32}$ M.C. Ricklefs, A History of Modern Indonesia Since c. 1200, (London: Palgrave, 2001), 229230.

${ }^{33}$ Zaprulkhan, "Dinamika Pemikiran Politik Islam di Indonesia"dalam Jurnal Review Politik (Surabaya: UIN Sunan Ampel), Vol. 3, No. 2, Desember 2013, 157.

${ }^{34}$ Greg Barton, Abdurrahman Wahid; Muslim Democrat, Indonesian President, (Australia: UNSW Press book, 2002), 73.
} 
kegiatan keagamaannya. Dukungan lainnya yaitu adanya pengangkatan pribumi menjadi sanyo, atau jabatan politik pada tiap-tiap departemen Indonesia. ${ }^{35}$ Selain itu, kebijakan-kebijakan Jepang lainnya yang sangat berpengaruh besar adalah pembentukan kantor urusan agama (Shumubu), Majelis Syuro Muslimin Indonesia (Masyumi), dan Hizbullah. ${ }^{36}$

\section{Masa Orde Lama}

Adanya paham nasionalis sekuler yang digagas oleh Soekarno dan temantemannya seperti yang telah dijelaskan sebelumnya tidak lepas dari hambatan. Gagasan yang lebih mengutamakan nasionalisme ketimbang ideologi ini $^{37}$ mendapat pertentangan dari golongan Islam. Mereka menentang pandangan yang menempatkan Islam berada di bawah payung kebangsaan. ${ }^{38}$ Menanggapi gagasan nasionalis Islam, seperti yang dikutip Sukron Kamil, Soekarno menjelaskan bahwa paham nasionalismenya bukan seperti corak Barat, akan tetapi corak ketimuran yang toleran, tidak agresif, yang hidup dalam kedamaian atas kehadiran Tuhan Yang Agung. ${ }^{39}$

Perbedaan adanya dua kelompok tentang dasar negara semakin nampak pada perumusan sila pertama. ${ }^{40}$ Meskipun para pendiri bangsa ini telah menerima pancasila sebagai dasar negara, sebagian Muslim lainnya meminta agar posisi Islam tercantum dalam konstitusi negara, yang mana aspirasi mereka ini dikenal dengan Piagam Jakarta dengan adanya penambahan kata-kata "kewajiban menjalankan syari'at Islam bagi para pemeluknya." Piagam Jakarta ini sempat disetujui untuk dimasukkan ke dalam UUD 1945, namun ditentang oleh kaum nasionalis ${ }^{41}$ dan akhirnya piagam tersebut tidak dicantumkan demi kesatuan bangsa Indonesia. ${ }^{42}$

Peristiwa tersebut menjadikan sejumlah kelompok Islam merasa kalah dan dikhianati. Maka muncullah berbagai pemberontakan yang terjadi di beberapa daerah di Indonesia. ${ }^{43}$ Di Jawa Barat, pada tahun 1949, Sekarmadji Maridjan Kartosuwirjo dan gerakan Darul Islam-nya melawan pemerintah pusat. Kemudian tepat pada tanggal 7

\footnotetext{
${ }^{35}$ Zaprulkhan, "Dinamika Pemikiran Politik Islam di Indonesia"dalam Jurnal Review Politik (Surabaya: UIN Sunan Ampel), Vol. 3, No. 2, Desember 2013, 157-158.

${ }^{36}$ Sukamto, Dinamika Politik Islam di Indonesia; Dari Masa Orde Baru Sampai Masa Reformasi, (Bandung: Enlightenment, 2008), 9.

${ }^{37}$ M.C. Ricklefs, A History of Modern Indonesia Since c. 1200, (London: Palgrave, 2001), 229230

${ }^{38}$ Tokoh-tokoh yang pemikirannya senada diantaranya adalah KH. Mas Mansur, Abdul Kahar Muzakkir, Ki Bagus Hadikusumo, KH. Masjkur, KH. A. Wahid Hasyim, Abikusumo Tjokrosujoso, H. Agus Salim, Sukiman Wirjosandjojo, KH. A. Sanusi, KH. Abdul Halim. Lihat Faisal Ismail, Islam, Politics and Ideology in Indonesia; A Study of The Process of Muslim Acceptance of The Pancasila, (Montreal: Canada, 1995), 21.

${ }^{39}$ Sukron Kamil, Islam dan Politik di Indonesia Terkini; Islam dan Negara, Dakwah dan Politik, HMI, Anti-Korupsi, Demokrasi, NI, MMI, dan Perda Syari'ah, (Ciputat: Pusat Studi Indonesia dan Arab, 2013), 6.

${ }^{40}$ Sukamto, Dinamika Politik Islam di Indonesia; Dari Masa Orde Baru Sampai Masa Reformasi, (Bandung: Enlightenment, 2008), 10.

${ }^{41}$ Ahmad Fuad Fanani dan Muhd. Abdullah Darraz, "Membaca Ulang Ekspresi Politik Umat Islam; Sebuah Pengantar," dalam MAARIF (Jakarta: MAARIF Institute for Culture and Humanity), Vol. 8, No. 2, Desember 2013, 4.

${ }^{42}$ Faisal Ismail, Islam, Politics and Ideology in Indonesia; A Study of The Process of Muslim Acceptance of The Pancasila, (Montreal: Canada, 1995), 3.

${ }^{43}$ Sukamto, Dinamika Politik Islam di Indonesia; Dari Masa Orde Baru Sampai Masa Reformasi, (Bandung: Enlightenment, 2008), 11. Lihat juga Sukron Kamil, Islam dan Politik di Indonesia Terkini; Islam dan Negara, Dakwah dan Politik, HMI, Anti-Korupsi, Demokrasi, NI, MMI, dan Perda Syari'ah, (Ciputat: Pusat Studi Indonesia dan Arab, 2013), 11.
} 
Agustus 1949, ia memproklamirkan Negara Islam Indonesia (NII) dan menyatakan bahwa dirinya sebagai Imam. Pada tahun 1952, Kahar Muzakkar yang berada di Sulawesi Selatan menyatakan penegakan sebuah negara Islam atas komando Kartosuwirjo. Perlawanan serupa juga terjadi di Aceh di bawah pimpinan Daud Beureueh yang juga mengajukan kepada pemerintah pusat. ${ }^{44}$

Adanya pemberontakan-pemberontakan tersebut tidak mengganggu hubungan baik antara Islam dan negara. Namun, kesepakatan yang terjadi pada 18 Agustus 1945 belumlah matang. Sehingga, persoalan negara sebagai dasar ideologi mencuat kembali selama masa kampanye pemilu $1955^{45}$ dan dalam perdebatan Majelis Konstituante. Majelis Konstituante dibuat untuk menyusun konstitusi permanen. ${ }^{46}$ Dalam sidangnya Majelis Konstituante, tugas-tugasnya dalam menyusun konstitusi sebenarnya sudah diselesaikan $90 \%$, diantaranya HAM, bentuk pemerintahan dan prinsip-prinsip kebijakan negara. Namun, permasalahan dasar negara yang berideologikan Islam atau bukan, tidak menemukan ujung kesepakatan. Hingga pada 2 Juni 1959 perdebatan tersebut menemukan keputusannya yang mana kedua kelompok tersebut sepakat bahwa Pancasila dijadikan sebagai dasar negara. ${ }^{47}$

Di masa berikutnya, pada masa demokrasi terpimpin, Soekarno memiliki porsi yang besar dalam memimpin bangsa. Hubungan Islam dan negara mulai memburuk. Hal ini ditandai dengan otoritas Soekarno pada tahun 1960 yang memberinya otoritas untuk melarang dan membubarkan partai-partai yang menentang negara. Politik Islam semakin melemah dengan dibubarkannya PSI dan Masyumi pada 17 Agustus 1960, hal ini dikarenakan PSI dan Masyumi tidak mengeksekusi anggota yang memberontak secara tegas, ${ }^{48}$ sehingga dianggap adanya keterlibatan para pemimpin Masyumi dengan pemberontakan daerah PRRI (Pemerintahan Revolusioner Republik Indonesia) atau Permesta (Perjuangan Semesta Alam). ${ }^{49}$

Keputusan dibubarkannya Masyumi dan PSI dari partai resmi bangsa secara simbolik menunjukkan bahwa nasionalis Islam berhasil dikalahkan. Namun, di antara kedua partai tersebut dan partai-partai lainnya yang mulai memudar, NU justru lebih dekat dengan Soekarno. Hal ini disebabkan karena dalam banyak hal, NU dan PNI memiliki banyak kesamaan ketimbang dengan Masyumi. Kedua partai ini mempunyai basis yang kuat di Jawa dan mencakup nilai-nilai Jawa, serta lebih menghargai gaya kepemimpinan tradisionalis dari pada cita-cita demokrasi Barat. ${ }^{50}$ Namun, pada

\footnotetext{
${ }^{44}$ Faisal Ismail, Islam, Politics and Ideology in Indonesia; A Study of The Process of Muslim Acceptance of The Pancasila, (Montreal: Canada, 1995), 60.

${ }^{45}$ Pada saat itu, partai Islam diwakilkan oleh Masyumi, NU, dan PSII (Partai Serekat Islam Indonesia).

${ }^{46}$ Greg Barton, Abdurrahman Wahid; Muslim Democrat, Indonesian President, (Australia: UNSW Press book, 2002), 74.

${ }^{47}$ Sukron Kamil, Islam dan Politik di Indonesia Terkini; Islam dan Negara, Dakwah dan Politik, HMI, Anti-Korupsi, Demokrasi, NI, MMI, dan Perda Syari'ah, (Ciputat: Pusat Studi Indonesia dan Arab, 2013), 12-14. 2010), 25

${ }^{48}$ Ken Ward, The Foundation of the Partai Muslimin Indonesia,(Singapore: Equinox Publishing,

${ }^{49}$ Sukron Kamil, Islam dan Politik di Indonesia Terkini; Islam dan Negara, Dakwah dan Politik, HMI, Anti-Korupsi, Demokrasi, NI, MMI, dan Perda Syari'ah, (Ciputat: Pusat Studi Indonesia dan Arab, 2013), 14

${ }^{50}$ Martin van Bruinessen, NU, Tradisi, Relasi-relasi Kuasa; Pencarian Wacana Baru,terj. Farid Wajidi (Yogyakarta: LkiS, 1999), 70.
} 
akhirnya partai NU pun jatuh di panggung perpolitikan bersama dengan gagalnya pemberontakan PKI pada $1965 .^{51}$

\section{Masa Orde Baru}

Gagalnya kudeta PKI di tahun 1965 dan turunnya mandat dari Soekarno kepada Soeharto yang dikenal dengan dengan Supersemar (Surat Perintah Sebelas Maret 1966) menandai berakhirnya Orde Lama dan digantikan oleh Orde Baru. ${ }^{52}$ Berbeda dengan Orde Lama, Orde Baru menggunakan cara berpikir yang berorientasi pada program. Belajar dari Orde Lama, pemerintahan terlalu sibuk dengan orientasi ideologi dalam hal pembangunan, sehingga menyebabkan kehancuran ekonomi karena perdebatan ideologi yang sengit. Oleh karena itu untuk memperbaiki pembangunan ekonomi, industralisasi atau pemenuhan kebutuhan dasar rakyat masa depan Indonesia harus bebas dari politik yang didasarkan kepada ideologi. ${ }^{53}$

Hal inilah yang menjadikan umat Islam merasa kecewa di masa Orde Baru. Pada awalnya pemimpin-pemimpin Muslim mengira bahwa dengan bergantinya Orde Lama dapat memberikan kesempatan untuk mengembalikan kekuatan politik Islam dan mulai menyusun rencana agar syari' at Islam masuk ke dalam sistem kenegaraan. ${ }^{54}$

Sebagai "Balas Budi" pemerintah Orde Baru atas partisipasi umat Islam dalam perjuangan melwan komunis, Partai Muslimin Indonesia (Parmusi) diizinkan oleh Soeharto berdasarkan Keputusan Presiden, No. 70, pada 20 Februari 1968 yang menyatakan bahwa Permusi merupakan sebuah persatuan organisasi sosial Islam yang tidak tergabung dalam partai politik. ${ }^{55}$ Namun, partai ini dipenuhi dengan konflik yang terjadi di dalam tubuh Parmusi sendiri. Pertikaian antara John Naro-Imran Kadir dan Djarnawi Hadikusuma-Lukman Harun mendorong pemerintah untuk turun tangan secara langsung dan memutuskan untuk menggantikan pimpinan Parmusi yang lama, Djarnawi Hadikusumo, kepada H.M.S Mintareja. ${ }^{56}$

Keputusan pemerintah, bagi sebagian kelompok seperti Muhammadiyah dan Keluarga Bulan Bintang justru mengecewakan. Keadaan tersebut terus berlanjut sampai menjelang pelaksanaan pemilihan umum pertama kali di era Orde Baru. Pemilu pertama tersebut yang dilaksanaan pada 1971 diikuti oleh 3 arus kekuatan politik. Kekuatan politik Islam diwakili oleh Parmusi, NU, PSII dan Perti, kemudian kekuatan nasionalis dan Kristen diwakili oleh PNI, IPKI, Parkindo, Partai Murba dan Partai Katolik, serta kekuatan nasionalis-pemerintah diwakili oleh Golkar. ${ }^{57}$ Golkar memenangkan mayoritas

\footnotetext{
${ }^{51}$ Mochamad Parmudi, "Islam dan Demokrasi di Indonesia; Dalam Perspektif Pengembangan Pemikiran Politik Islam”, Laporan Hasil Penelitian Individual, IAIN Walisongo, 2014, 135.

${ }^{52}$ Mengenai makna Orde Baru, Soeharto berkata: "yang dimaksud dengan Orde Baru ialah peraturan kehidupan masyarakat bangsa dan negara yang kita letakkan kembali kepada kemurnian pelaksanaan Pancasila dan UUD 1945. Dikutip oleh Okrisal Eka Putra, "Hubungan Islam dan Politik Masa Orde Baru,” dalam Jurnal Dakwah, Vol. IX, No. 2, Juli-Desember 2008, 185-186.

${ }^{53}$ M. Syafi'i Anwar, Pemikiran dan Aksi Islam Indonesia; Sebuah Kajian Politik tentang Cendikiawan Muslim Orde Baru, (Jakarta: PARAMADINA, 1995), 19-20.

${ }^{54}$ Mochamad Parmudi, "Islam dan Demokrasi di Indonesia; Dalam Perspektif Pengembangan Pemikiran Politik Islam”, Laporan Hasil Penelitian Individual, IAIN Walisongo, 2014, 140.

${ }^{55}$ Ken Ward, The Foundation of the Partai Muslimin Indonesia,(Singapore: Equinox Publishing, 2010), 51-52.

${ }^{56}$ M. Syafi'i Anwar, Pemikiran dan Aksi Islam Indonesia; Sebuah Kajian Politik tentang Cendikiawan Muslim Orde Baru, (Jakarta: PARAMADINA, 1995), 36.

${ }^{57}$ Mochamad Parmudi, "Islam dan Demokrasi di Indonesia; Dalam Perspektif Pengembangan Pemikiran Politik Islam”, Laporan Hasil Penelitian Individual, IAIN Walisongo, 2014, 144.
} 
suara di setiap provinsi, kecuali di Aceh, Jakarta dan Maluku dan tetap mendapatkan suara terbanyak, yaitu $62,8 \% .^{58}$

Pada bulan Januari 1973, pemerintah mendesak partai-partai yang ada dilebur menjadi 2 partai. Partai-partai Islam seperti NU dan Parmusi dilebur menjadi PPP (Partai Persatuan Pembangunan) dan partai yang berbasis nasionalis dan non-Islam diantaranya Murba, PNI, Katolik, Kristen dan IPKI dientuk PDI (Partai Demokrasi Indonesia). Selanjutnya pada bulan Maret 1973, MPR baru menunjuk Soeharto untuk memimpin Indonesia sebagai Presiden untuk kedua kalinya. ${ }^{59}$

Sepanjang 32 tahun masa Orde Baru, hubungan Islam dan negara dapat dibedakan menjadi 2 periode. Pertama, periode antagonistik (1966-1985). Periode ini terdiri dari dua babak. Babak pertama yaitu hingga tahun 1981, dimana ketika umat Islam secara bulat menentang dan bertolak belakang dengan kebijakan pemerintah, karena dianggap tidak sesuai dengan aspirasi umat Islam. Di antara aspirasi tersebut adalah menolak rehabilitasi Masyumi, melarang adanya PDII (Partai Demokrasi Islam Indonesia) yang digagas oleh Moh. Hatta, rumusan rancangan undang-undang tentang perkawinan, mengganti pelajaran agama dengan Pancasila ke dalam kurikulum pendidikan Indonesia, melarang siswi Muslimah menggunakan hijabnya, dan legislasi perjudian oleh negara. Babak kedua dari periode ini adalah tahun 1982-1985, dimana umat Islam mulai sejalan dalam merespon kebijakan Orde Baru, meskipun ada sebagian yang masih bersikap oposisi dan sebagiannya lagi lunak dengan kebijakan negara. Hal ini dikarenakan banyak cendikiawan dan kelas menengah umat Islam yang masuk dalam jajaran pemerintahan, serta Orde Baru memandang bahwa Islam adalah kekuatan yang tidak bisa dinafikan, dan harus lebih berhati-hati dalam menetapkan kebijakankebijakan. ${ }^{60}$

Kedua, periode akomodatif (1985-1998). Pada periode ini pemerintah menunjukkan sikap akomodatif terhadap Islam. Di antara sikap tersebut adalah banyak dari kalangan Muslim yang menduduki jabatan di berbagai lembaga. Hal ini tidak terlepas dari usaha Nurcholis Madjid dalam mencairkan hubungan antara Islam dan negara yang dikenal dengan Islam kultural. ${ }^{61}$ Hingga pada tahun 1990, pemerintah dan umat Islam menjalani hubungan yang mesra, ketika para tokoh Muslim banyak memegang jabatan yang strategis di pemerintahan. Namun, jika diakumulasikan hubungan Islam dan pemerintah dari masa orde lama hingga orde baru menunjukkan bahwa politik Islam kurang leluasa dalam mengapresiasikan gagasan-gagasannya. Sehingga pada masa orde baru Islam politik yang diartikan sebagai gerakan umat Islam dalam mengapresiasikan gagasan-gagasannya melalui saluran perpolitikan mengganti strateginya yang menitikberatkan pada Islam kultural. Hal ini dilakukan para cendikiawan Muslim untuk menghilangkan stigma negatif akan radikalisme politik Islam selama masa orde lama. ${ }^{62}$

\footnotetext{
${ }^{58}$ M.C. Ricklefs, A History of Modern Indonesia Since c. 1200, (London: Palgrave, 2001), 361.

${ }^{59}$ M.C. Ricklefs, A History of Modern Indonesia Since c. 1200, (London: Palgrave, 2001), 361.

${ }^{60}$ Mochamad Parmudi, "Islam dan Demokrasi di Indonesia; Dalam Perspektif Pengembangan Pemikiran Politik Islam", Laporan Hasil Penelitian Individual, IAIN Walisongo, 2014, 145-147.

${ }^{61}$ Wacana mengenai Islam kultural memang mulai dikenal masyarakat luas pada masa Orde Baru. Namun, perlu ditarik kepada sejarah politik Islam di era pra-kemerdekaan bahwa Islam kultural telah ada sejak saat itu. Serekat Dagang Islam (SDI) sebelum berganti menjadi Serekat Islam (SI) merupakan sebuah organisasiyang bisa dibilang sebagai wadah kebudayaan yang menampung aspirasi umat Islam tanpa mengaitkannya dalam kancah perpolitikan.

${ }^{62}$ Mochamad Parmudi, "Islam dan Demokrasi di Indonesia; Dalam Perspektif Pengembangan Pemikiran Politik Islam”, Laporan Hasil Penelitian Individual, IAIN Walisongo, 2014, 153.
} 


\section{E. Embrio Islam Kultural di dalam konteks Indonesia}

Konsep modernisasi yang diusung oleh Orde Baru bukan tanpa masalah bagi umat Islam, karena modernisasi masih merupakan persoalan yang relatif baru. Umat Islam dalam posisi dilematis, antara mendukung atau menolak. Mendukung artinya ikut serta dan berpartisipasi dalam kebijakan rezim baru yang berarti jelas-jelas mendukung modernisasi dengan preferensi ideologis Barat. Atau menolak dengan konsekuensi kehilangan kesempatan untuk berpartisipasi secara aktif dalam program pembangunan yang sudah mendapat dukungan luas dari berbagai pihak - termasuk pihak luar Islam. Dilema tersebut menimbulkan perbedaan di kalangan kaum muslimin dalam merespon modernisasi yang diusung Orde Baru ${ }^{63}$ teradapat beberapa tipologi.

Pertama, tipologi apologi yang kemudian diikuti dengan usaha penyesuaian

diri dan adaptasi terhadap proses modernisasi.

Tipologi kedua, juga melakukan apologi terhadap ajaran Islam tapi menolak modernisasi yang dinilai sebagai westernisasi dan sekularisasi. Tipologi itumelakukan resistensi secara formal, dalam praktik pemikirannya sangat kaku (rigid) dan cenderung tunggal.

Tipologi ketiga, adalah mengambil pola tanggapan yang kreatif dengan menempuh jalan dialogis dengan mengutamakan pendekatanintelektual. ${ }^{64}$

Dari ketiga tipologi tersebut, tipologi yang ketigalah yang paling populer yang di usung dalam gerakan pembaharuan pemikiran Islam kontemporer oleh salah satu tokoh pembaharuan yang di pelopori oleh, Nurkholis Majid yang di kenal pada saat itu adalah pemuda penyebab munculnya gerakan Islam kultural.

Orientasi politik berkuasa dimulainya pada zaman Orde Baru secara kritis Islam kultural memandang bahwa, sejak sepuluh tahun berkuasa telah menempatkan Islam pada posisi yang menguntungkan. Kesan bahwa Islam itu tradisionalis, anti modernisasi, anti pembangunan bahkan anti Pancasil, telah menempatkan umat Islam pada posisi marjinal. Dari sinilah munculnya gerakan baru pemikiran Islam.

Kedua pilihan ini memang mengandung resiko. Namun demikian, kemungkinan resiko pecahnya umat Islam tidak menghalanginya untuk melakukan perumusan tentang pemahaman keislaman yang lebih segar dan bertenaga, Alasan lainnya adalah secara kuantitas posisi umat Islam yang makin bertambah, dan diduga bahwa mayoritas Muslim ingin mengetahui berbagai persoalan keislaman. Dari realitas itulah Islam Kultural lebih concern dan terikat pada Islam dan umatnya, bukan pada kelembagaannya seperti partai politik Islam maupun wadah persatuan bagi umat Islam. $^{65}$

Pemikiran Nucholish dan Islam Kultural tersebut lebih pada semangat substansinya ketimbang pada simbol-simbol distingtif. Bagi Islam Kultural, sebutan "negara Islam" atau "Islam sebagai dasar negara" bukanlah faktor yang paling utama. Tapi yang lebih penting adalah men-transformasi-kan prinsip-prinsip dan nilai-nilai universal Islam ke dalam praktik penyelenggaraan negara. Karenanya Nurcholish menjadi optimis, bahwa nilai-nilai Islam di Indonesia yang akan membentuk wawasan kemodernan Indonesia - jikalau umat Islam mau menengok sejarahnya sendiri di mana

63 Dawam Raharjo, Islam dan Modernisasi: Catatan atas Paham Sekularisasi Noercholis Madjid, sebagai kata pengantar buku Noercholish Madjid, Islam Kemodernan dan Keindonesiaan, (Bandung: Mizan, 1987), 13.

${ }^{64}$ Syafi'I Anwar, Pemikiran dan Aksi Islam, (Jakart: Paramidina, 1995), 6.

${ }^{65}$ Nurcholish Majid, Islam kemodernan dan keIdnoensiaan, (Bandung: Mizan, 1993), 204. 
Islam pernah menjadi suri tauladan sebagai sebuah sistem politik yang modern pada masa itu. ${ }^{66}$

Pada kenyataan bangsa Indonesia dan umat Islam yang plural, benar-benar merupakan tantangan sekaligus sebuah kenyataan. Ketika sebagian umat Islam masih terobsesi tentang pentingnya pembangunan Islam politik secara formal dalam kekuasaan. Maka cara pandang keagamaan kaum muslimin terjebak pada cara pandang politis-idiologis. Cara pandang tersebut, dalam kegelisahan Nurcholish dipandang sebagai historis.

Dapat dilihat bahwa dengan gerakan 'Islam Kultural'-nya Nurcholish melakukan pembaharuan dan pencerahan pemikiran -- include di dalamnya pemikiran politik Islam, mulai dari pemikirannya tentang 'Islam, Yes, Partai Islam, No' dan pemikiran politik Islam lainnya yang sangat substantif. Islam sebagai sebuah diktum yang tetap,maka ia bersifat eternal dan essensial, tapi ketika Islam menjadi sebagai produkpenafsiran sejarah dan budaya, maka la akan mengalami desakralisasi.

\section{F. Perkembangan Islam Kultural dan Momentum Kebangkitan Partai Islam}

Sering diperdengarkan Istilah Islam kultural sering digunakan untuk menyebut gerakan Islam yang membedakannya dari Islam struktural. Keduanya merupakan penanda bagi apa yang disebut model Gerakan Islam Indonesia pada tahun 1980-an. Keduanya adalah model dari pilihan strategi arus atas dan strategi arus bawah yang mewakili dua eksonen penting saat itu yaitu Amien Rais dan Abdurrahman Wahid sebelum kedunya masuk ke gelanggang politik secara langsung. Sebagai pilihan strategi maka sudah pasti ditentukan Islam kultural dan Islam struktural itu ditentukanberdasarkan pembacaan terhadap makna Isam dalam kaitannya.

Berdasarkan pengalaman sejarah menunjukkan bahwa Islam Politik hanya melahirkan perpecahan dan tidak menimbulkan sinergi antara umat Islam maka munculah adigium yang mengkritik kondisi Islam di dunia perpolitikan yang populer pada tahun 1970-an yang dilontarkan oleh seorang cendikia muda Nurcholis Madjid 'Islam Yes, Politik Islam No' konsesi ini menekankan akan sekulerisasi pergerakan Islam dalam bidang politik, Islam harus lebih berperan sebagai pandu moral dan sosial yang tercermin dalam konsepnya yang terkenal yaitu Islam kultural. Gerakan ini memperoleh sambutan positif dari kalangan Nahdlatul Ulama (NU) dengan mundur dari kancah politik dan bersifat kooperatif terhadap pemerintah.

Gerakan Islam kutural dimulai sejak tahun 1970 sebagai sebuah gerakan kaum cendikia yang mencoba memobilisasi pikiran masyarakat untuk tidak selalu terfokus pada gerakan politik yang hanya menimbuklan perpecahan. Sesuai dengan pendapat Buya Syafii Maarif yang menyatakan:'Politik hanya memecah belah dan menciptakan lawan, sedangkan dakwah berkeinginan merangkul dan memperbanyak kawan. Tentu hal itu itu tidak bisa dipungkiri begitu saja, sebab dengan berpolitik umat menjadi miopis, hanya mampu melihat realitas-realitas jangka pendek."

Istilah Islam kultural nampaknya ingin mengkontraskan Islam politik. Namun demikian, kemunculan Islam kultural sebenarnya bukan untuk menegasikan Islam politik melainkan sebuah solusi atau alternatif atas kebuntuan Islam politik di Indonesia, baik pada masa awal kemerdekaan, revolusi, Demokrasi Parlementer, Demokrasi Terpimpin, dan awal Orde Baru.

\footnotetext{
${ }^{66}$ Nurcholish Madjid, Cita-cita Politik Islam Era Reformasi, (Jakarta, Paramadina, 1999), 35.
} 
Islam kultural mempunyai arti bahwa Islam merupakan salah satu komponen yang membentuk, melandasi, dan mengarahkan bangsa dan negara. Dalam hal ini, Islam kultural tidak mengharuskan terbentuknya negara Islam. Yang paling penting menurut Islam kultural adalah dilaksanakannya nilai-nilai substansi Islam yaitu keadilan, kesamaan, partisipasi, dan musyawarah. ${ }^{67}$ Dengan menolak partai politik sebagai wahana pokok perjuangan Islam, Nurcholish Madjid secara tegas menentang gagasan negara Islam. Gagasan Nurcholish Madjid ini menitikberatkan pada usaha pembaruan keagamaan dan etika serta membuka diri terhadap kerjasama dengan kelompokkelompok masyarakat di luar umat Islam.

Dengan berkembangnya gerakan Islam kultural pada masa Orde Baru, banyak pengamat menilai bahwa kekuatan Islam politik tidak akan muncul lagi. Apalagi setelah PPP sebagai satu-satunya representasi kekuatan Islam politik sudah menanggalkan asas Islam dan menerima asas Pancasila. Taufik Abdullah mengatakan bahwa dengan PPP menerima Pancasila sebagai asasnya maka hal itu merupakan "halaman akhir Islam politik di Indonesia". 68

Sebagaimana diketahui bahwa Indonesia pasca Orde Baru, akibat gerakan reformasi yang dipelopori mahasiswa, telah terjadi ledakan partisipasi politik. Ledakan partisipasi politik itu bukan hanya menimpa kalangan masa akar rumput tetapi juga menghinggapi kalangan elite politik. Sebagai perwujudan dari ledakan partisipasi politik itu, para elite politik berlomba-lomba mendirikan atau menghidupkan kembali partai politik, tak terkecuali elite Islam. Partai-partai politik Islam yang muncul pada era reformasi ini mencapai 32, dan dari jumlah tersebut yang lolos Pemilu 1999 sebanyak 17 partai. $^{69}$

Fenomena berdirinya partai-partai politik, khususnya yang berbasis Islam, dianggap sebagai bangkitnya politik aliran. Dikatakan sebagai bangkitnya kembali politik aliran karena selama Orde Baru, politik aliran diberangus. Pada masa itu, rezim Orde Baru melakukan kebijakan dealiranisasi dengan serangkaian kebijakan: depolitisasi massa, floating mass, dan de-ideoligisasi dengan memberlakukan Pancasila sebagai asas tunggal. Kini setelah rezim Orde Baru jatuh, aliran-aliran politik itu, termasuk aliran politik Islam, bangkit kembali dengan wujud berdirinya partai-partai politik Islam.

\section{G. Kesimpulan}

Dapat disilmpulkan dari artikel di atas bahwa Islam kultural boleh saja di galakkan akan tetapi, bukan berarti meninggalkan Islam secara politik. Karena Islam politik dan Islam kultural merupakan menjadi sebuah perdebatan oleh para cendekiawan muslim, Semakin besar gerakan politik Islam pada tataran ideologis menyebabkan kekuatan umat Islam semakin melemah dan mengalami stagnansi. Oleh karena itu dalam gerakan perjuangan umat Islam disuguhkan sebuah konsep yang lain yang bergerak secara kultural sebagai alternatif agar umat Islam tidak lagi mengalami keterlambatan pembangunan. Hal ini yang ditekankan oleh Nurkholis Majid sehingga ia sendiri cendrung menganggap kemunculan partai-partai Islam menyebabkan munculnya

${ }^{67}$ Bahtiar Effendy, Islam dan Negara, Transformasi Pemikiran dan Praktik Politik Islamdi Indonesia, (Jakarta: Paramadina, 1998), 16.

${ }^{68}$ Muh. Syamsuddin dan Muh. Fatkhan, Dinamika Islam Pada Masa Orde Baru, Jurnal Dakwah, Vol.XI No.2 (Juli-Desember 2010), 149-150.

${ }^{69}$ Lili Romli, Partai Islam dan Pemilih Islam di Indonesia, Jurnal Penelitian Politik, Vol. 1 No.1 (2004), 29-48. 
gejala komunalisme. Semakin besar gerakan politik Islam pada tataran ideologis menyebabkan kekuatan umat Islam semakin melemah dan mengalami stagnansi. Oleh karena itu dalam gerakan perjuangan umat Islam disuguhkan sebuah konsep yang lain yang bergerak secara kultural sebagai alternatif agar umat Islam tidak lagi mengalami keterlambatan pembangunan. Hal ini yang ditekankan oleh Nurkholis Majid sehingga ia sendiri cendrung menganggap kemunculan partai-partai Islam menyebabkan munculnya gejala komunalisme.

\section{DAFTAR PUSTAKA}

Abdillah, Masykuri, Islam Politik dan Islam Struktural, dalam Hamid Habaib, dkk, Mengapa Partai Islam Kalah?: Perjalanan Politik Islam dari Prapemilu '99 sampai Pemilihan Presiden, Jakarta: Alvaabet: 1999

Ahmad Fuad Fanani dan Muhd. Abdullah Darraz, "Membaca Ulang Ekspresi Politik Umat Islam; Sebuah Pengantar," dalam MAARIF (Jakarta: MAARIF Institute for Culture and Humanity), Vol. 8, No. 2, Desember 2013

Al-Zastrouw , Ngatawi, Mengenal Sepintas Islam Nusantara, Indonesian Journal of Multidisciplinary Islamic Studies,Vol.1, No.1, Januari 2017

Anwar, Syafi'I Pemikiran dan Aksi Islam, Jakart: Paramidina, 1995

Azra, Azyumardi, "Islam Politik dan Islam Kultural": Islam Masa Pasca-Soeharto.

Azra, Azyumardi, Revisitasi Islam Politik dan Islam Kultural di Indonesia, IndoIslamika, Vol.1 No.2 (2012).

Azyumardi Azra, Jaringan Ulama, Bandung: Mizan, 1998

Bassam Tibi, Krisis Modern dalam Peradaban Islam.

Bruinessen, Martin van, NU, Tradisi, Relasi-relasi Kuasa; Pencarian Wacana Baru,terj. Farid Wajidi Yogyakarta: LkiS, 1999

Buchori, Didin Saefuddin, Sejarah Politik Islam Jakarta: Pustaka Intermasa, 2009

Effendy, Bahtiar, Islam dan Negara, Transformasi Pemikiran dan Praktik Politik Islamdi Indonesia, Jakarta: Paramadina, 1998.

Greg Barton, Abdurrahman Wahid; Muslim Democrat, Indonesian President, Australia: UNSW Press book, 2002

Ismail, Faisal, Islam, Politics and Ideology in Indonesia; A Study of The Process of Muslim Acceptance of The Pancasila, Montreal: Canada, 1995

Jamil, M. Mukhsin, Revitalisasi Islam Kultural, Jurnal Walisongo Vol.21 No.2 November 2013

Kamil, Sukron, Islam dan Politik di Indonesia Terkini; Islam dan Negara, Dakwah dan Politik, HMI, Anti-Korupsi, Demokrasi, NI, MMI, dan Perda Syari'ah, (Ciputat: Pusat Studi Indonesia dan Arab, 2013

Kuntowijoyo, Dinamika Sejaarah Islam Indonesi, Yogyakarta: Salahuddin Perss 1991.

M. Syafi'i Anwar, Pemikiran dan Aksi Islam Indonesia; Sebuah Kajian Politik tentang Cendikiawan Muslim Orde Baru, Jakarta: PARAMADINA, 1995

Maarif, Ahmad Syafii Maarif, Islam dan Pancasila Sebagai DasarNegara: Studi Tentang Perdebatan dalam Konstituante, Cet I Bandung:Mizan, 2017

Majid, Nurcholish Islam kemodernan dan keIdnoensiaan, Bandung: Mizan, 1993.

Majid, Nurcholish, Cita-cita Politik Islam Era Reformasi , Jakarta, Paramadina, 1999. 
Noer, Deliar, Islam dan Politik, dalam Hamid Habaib, dkk, Mengapa Partai Islam Kalah?: Perjalanan Politik Islam dari Prapemilu '99 sampai Pemilihan Presiden, Jakarta: Alvaabet: 1999

Parmudi, Mochamad, "Islam dan Demokrasi di Indonesia; Dalam Perspektif Pengembangan Pemikiran Politik Islam", Laporan Hasil Penelitian Individual, IAIN Walisongo, 2014

Putra, Okrisal Eka, "Hubungan Islam dan Politik Masa Orde Baru," dalam Jurnal Dakwah, Vol. IX, No. 2, Juli-Desember 2008

Raharjo, Dawam, Islam dan Modernisasi: Catatan atas Paham Sekularisasi Noercholis Madjid, sebagai kata pengantar buku Noercholish Madjid, Islam Kemodernan dan Keindonesiaan, Bandung: Mizan, 1987

Ricklefs, M.C, A History of Modern Indonesia Since c. 1200, London: Palgrave, 2001

Ricklefs, M.C. A History of Modern Indonesia Since c. 1200, London: Palgrave, 2001

Rijal Mumazziq Zionis, Rijal, Konsep Kenegaraan dalam Islam : Perdebatan yang tak kunjung Tuntas,Jurnal Falasifa, Vol.1 No.2 September 2010.

Romli, Lili, Partai Islam dan Pemilih Islam di Indonesia, Jurnal Penelitian Politik, Vol. 1 No.1 2004

Scharz, Adam, A Nation in Waiting; Indonesia's Search for Stability, (United States of America: Westview Press, 2000

Subhan, Arif, Inodnesia dalam Transisi Menuju Demokrasi, (Jakarta: LSAF, 1999).

Sukamto, Dinamika Politik Islam di Indonesia; Dari Masa Orde Baru Sampai Masa Reformasi, Bandung: Enlightenment, 2008

Syamsuddin, Muh. dan Muh. Fatkhan, Dinamika Islam Pada Masa Orde Baru, Jurnal Dakwah, Vol.XI No.2 Juli-Desember 2010

Syamsuddin, Din dan Muh. Fatkhan, Dinamika Islam Pada Masa Orde Baru, Jurnal Dakwah, Vol.XI No.2 Juli-Desember 2010

Syamsuddin, Din, “Usaha Pencarian Konsep NegaraDalam Sejarah Pemikiran Politik Islam", Ulumul Qur'an, No.2 Vol.IV tahun 1993.

Umaruddin, Membaca Pikiran Gus Dur dan Amien RaisTentang Demokrasi, (Yogyakarta: Pustaka Pelajar), 1999

Vlekke, Bernard H. M, Nusantara; Sejarah Indonesia, terj. Samsudin Berlian, Jakarta: PT Gramedia, 2008

Ward, Ken, The Foundation of the Partai Muslimin Indonesia, Singapore: Equinox Publishing, 2010

Ward, Ken, The Foundation of the Partai Muslimin Indonesia,(Singapore: Equinox Publishing, 2010), h. 51-52. Anwar, M. Syafi'i, Pemikiran dan Aksi Islam Indonesia; Sebuah Kajian Politik tentang Cendikiawan Muslim Orde Baru, Jakarta: PARAMADINA, 1995

Zaprulkhan, "Dinamika Pemikiran Politik Islam di Indonesia"dalam Jurnal Review Politik (Surabaya: UIN Sunan Ampel), Vol. 3, No. 2, Desember 2013

Zaprulkhan, Dinamika Pemikiran Politik Islam di Indonesia, Jurnal review Politik Vol.3 No. 2 Desember 2013 